\title{
Factors Associated with Height of Medical Student at Warmadewa University
}

\author{
K T Sumadewi ${ }^{1 *}$, M C K Dipa ${ }^{1}$, I G N P Sana ${ }^{1}$ \\ ${ }^{1}$ Faculty of Medicine and Health Sciences, Universitas Warmadewa, Bali, Indonesia \\ *drtriscel@gmail.com
}

\begin{abstract}
Short body height will be a problem if the prevalence of short stature is high $(30-39 \%)$ and very high $(\geq 40 \%)$. In $2013,41.6 \%$ of Indonesian women aged $>18$ years old had short height. Short women tend to have risky pregnancies and give birth to short children as well. This research was aimed to determine factors associated with height of the medical students at Warmadewa University. An analytic cross sectional method was used and 66 samples were chosen using systematic random sampling technique. The data were analyzed by correlation test of contingent coefficient with $p<0,05$. The results of this study shows significant correlations between height of female students with both their birth weight ( $p=0,016, C=285$ ) and height of parent (father's height: $p=0,031, C$ $=0,256$; mother's height: $\mathrm{p}=0,045, \mathrm{C}=240$ ). No significant correlation between height of female students and their age of menarche $(p=0,084, C=208)$. In conclusion, the height of the parent body and the birth weight has correlation with the height of the female medical students, while the age of menarche have no significant correlation with height of female students at Warmadewa University.
\end{abstract}

Keyword : Associated, Medical Student, Warmadewa University.

\section{Introduction}

Puberty is a period when children experience sexual function maturation. There are five specific changes at puberty, one of which is rapid height gain. There are differences in the rate of growth in height between boys and girls. Boys grow about $10 \mathrm{~cm}$ per year with a peak of maximal growth at the age of 14 years old, while girls grow approximately $9 \mathrm{~cm}$ per year and peak of maximum growth at the age of 12 years old [1].

According to WHO 2007, a short height will become a problem if the prevalence of shortness is classified as high at $30-39 \%$ and very high at $\geq 40 \%$. In Indonesia, the prevalence of short women aged > 18 years in 2013 amounted to $41.6 \%$, which was categorized into short skinny $(4.8 \%)$, normal short $(29.9 \%)$ and short fat $(10.9 \%)$. Short women will experience high-risk pregnancies (height $<150 \mathrm{~cm}$ ). In Indonesia the prevalence of high-risk pregnant women is $31.3 \%$. Short women also tend to give birth to small babies, who have a risk to become short adults as well. This problem will continue to recur and get worse if no serious actions are taken [2]. Height is influenced by many factors including menarche age, parental height, and birth weight $[3,4,5]$. This study aimed to determine the relationship between age of menarche, parental height and birth weight with the height of female students of the Faculty of Medicine and Health Sciences, Warmadewa University. 


\section{Method}

This research was conducted at the Faculty of Medicine and Health Sciences of Warmadewa University in September-December 2017. A cross sectional analytical method was used to determine the relationship between menarche age, birth weight and parental height with the height of female students in Faculty of Medicine and Health Sciences of Warmadewa University. The population in this study was female students in 2014-2017 period of Faculty of Medicine and Health Sciences of Warmadewa University. Samples that met the inclusion criteria were selected using systematic random sampling technique. Respondents' data were obtained through direct interviews using prepared questionnairesand analyzed using correlation coefficient contingency test to find out the relationship between independent and dependent variables. In this analysis, a significance of 0.05 was used.

\section{Results And Discussion}

The age range of the samples in this study was 18-22 years. As can be seen in Table 1, most samples were at the age of 20 years $(34.8 \%)$ and the least were at the age of 22 years $(6.1 \%)$. The respondents had high stature $(78.8 \%)$, slow menarche age $(56.1 \%)$, high father's height (83.3\%), high mother's height (59.1\%) and normal birth weight (84.8\%).

Table 1. Characteristics of Samples

\begin{tabular}{lcc}
\hline \multicolumn{1}{c}{ Characteristics } & Frequency & Percentage (\%) \\
\hline Age & & \\
19 years old & 20 & 30,3 \\
20 years old & 23 & 34,8 \\
21 years old & 19 & 28,8 \\
22 years old & 4 & 6,1 \\
Body Height & & \\
$\quad$ Short & 14 & 21,2 \\
$\quad$ High & 52 & 78,8 \\
Age of Menarche & & \\
$\quad$ Early & 29 & 43,9 \\
Late & 37 & 56,1 \\
Father's Body Height & & \\
Short & 11 & 16,7 \\
$\quad$ High & 55 & 83,3 \\
Mother's Body Height & & \\
Short & 27 & 40,9 \\
$\quad$ High & 39 & 59,1 \\
Birth Weight & & \\
$\quad$ Low & 10 & 84,2 \\
$\quad$ Normal & 56 & \\
\hline
\end{tabular}

The age range of the sample used in this study was 18-22 years. Based on the table above, most samples were at the age of 20 years (23 samples) and the least were at the age of 22 years (4 samples). Based on table 1, the female students in Faculty of Medicine and Health 
Sciences Warmadewa University had higher (78.8\%), slow menarche age $(56.1 \%)$, high father's height (83.3\%), high mother's height (59.1\%) and normal birth weight $(84.8 \%)$.

Table 2. Relationship between Menarche Age and Sample Height

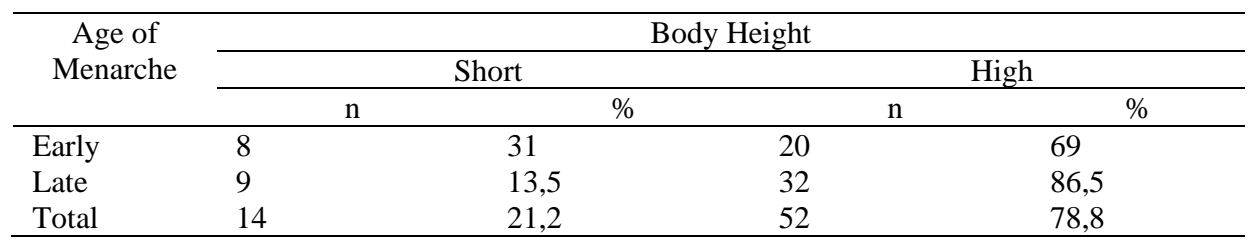

Table 2 show the result of contingency coefficient analyze. The results of the contingency coefficient correlation test show that there was no significant relationship between age of menarche and height, with p of 0.084 and $\mathrm{C}$ of 0.208 .

Table 3. Correlation between Father's Height and Sample's Height

\begin{tabular}{llrllll}
\hline \multirow{2}{*}{$\begin{array}{c}\text { Father's } \\
\text { body height }\end{array}$} & \multicolumn{5}{c}{ Body Height } \\
\cline { 2 - 7 } & & $\mathrm{n}$ & Short & \multicolumn{3}{c}{ High } \\
\hline Short & 5 & & $\%$ & 6 & $\mathrm{n}$ \\
High & 9 & 45,5 & 46 & 54,5 \\
Total & 14 & 16,4 & 52 & 83,6 \\
\end{tabular}

Table 3 show the results of contingency coefficient correlation test show that there was a weak significant relationship between father's height and the height of female students in Faculty of Medicine of Warmadewa University, with $\mathrm{p}=0.031$ and $\mathrm{C}=0.256$.

Table 4. Relationship between Mother's Body Height and Sample Height

\begin{tabular}{|c|c|c|c|c|}
\hline \multirow{3}{*}{$\begin{array}{c}\text { Mother's } \\
\text { Body Height }\end{array}$} & \multicolumn{4}{|c|}{ Body Height } \\
\hline & \multicolumn{2}{|c|}{ Short } & \multicolumn{2}{|c|}{ High } \\
\hline & $\mathrm{n}$ & $\%$ & & $\%$ \\
\hline Short & 9 & 33,3 & 18 & 66,7 \\
\hline High & 5 & 12,8 & 34 & 87,2 \\
\hline Total & 14 & 21,2 & 52 & 78,8 \\
\hline
\end{tabular}

Table 4 show the results of contingency coefficient correlation test showed that there was a weak significant relationship between the height of the mother and the height of the female students in Faculty of Medicine of Warmadewa University, with values $\mathrm{p}=0.045$ and $\mathrm{C}=$ 0.240 .

Table 5. Relationship between Birth Weight and Sample Heigh

\begin{tabular}{|c|c|c|c|c|}
\hline \multirow{3}{*}{ Birth Weight } & \multicolumn{4}{|c|}{ Body Height } \\
\hline & \multicolumn{2}{|c|}{ Short } & \multicolumn{2}{|c|}{ High } \\
\hline & $\mathrm{N}$ & $\%$ & $\mathrm{~N}$ & $\%$ \\
\hline Low & 5 & 50 & 5 & 50 \\
\hline Normal & 9 & 16,1 & 47 & 83,9 \\
\hline Total & 14 & 21,2 & 52 & 78,8 \\
\hline
\end{tabular}


Table 5 show the results of contingency coefficient correlation test showed that there was a weak significant relationship between birth weight and the height of the female students in Faculty of Medicine of Warmadewa University, with values $\mathrm{p}=0.016$ and $\mathrm{C}=0.285$.

\subsection{Relationship between Age of Menarche and Sample's Height}

Contingency coefficient correlation test results show that there was no relationship between age of menarche and height, with $p=0.084$. These results are in line with research that states that there was no relationship between age of menarche and height $[5,6]$. This is because many factors affect height including poor sanitation and frequent illness at the age of two years old, family socioeconomic, high parental body, birth weight, and exercise [3,5,7].

Research on the relationship between age of menarche and height is still debated. The results of this study are not in accordance with a study by Chang (2000) which supported the hypothesis that body height reaching its peak at one year before menarche but slowing and stopping one year after menarche caused by epiphysial closing so that women who experiencing earlier menarche will have a shorter body [8]. Whereas, a research on the relationship between age of menarche and height at the Faculty of Medicine, Surakarta State University reported a correlation with negative direction $(\mathrm{p}=-0.603)$ between age of menarche and body height, where the younger the age of menarche, the higher her height [9].

\subsection{Relationship between Birth Weight and Sample's Height}

Contingency coefficient correlation test results show that there was a significant relationship between birth weight and height of female students in Faculty of Medicine of Warmadewa University, with a value of $p=0.016$. Birth weight is one of the factors that affects height. Birth weight is a predictor of adult height that is more accurate than weight gain during pregnancy. Each kilogram of birth weight has an effect of $3 \mathrm{~cm}$ on adult height. Someone who has a birth weight of 4,000 grams is $9 \mathrm{~cm}$ higher than someone who has a low birth weight [3].

\subsection{Relationship between Parent's Height and Sample's Height}

Based on the contingent coefficient correlation test, between parent's height (father and mother) and height showed a significant relationship $(\mathrm{p}<0.05)$, where father's height had $\mathrm{p}=$ 0.031 and mother's height $p=0.045$. These results are in line with research that concludes that fathers who have short stature were at risk of having stunting children [10]. Likewise with research that concludes that mother's height is one of the risk factors for stunting [11].

Short events were greater in respondents who had shorter fathers as well as the mothers' height. Based on the chi square test, Prasetyarini (2012) draws the conclusion that respondents who have short fathers and mothers were three times more at risk of experiencing short events (father's height $\mathrm{OR}=3.300$; mother's height $\mathrm{OR}=3.391$ ) [5].

Height is one form of genetic expression, and being a factor that is passed on to children and is related to the incidence of stunting. Children with short parents, either one or both, are more at risk of stunting when compared to children who have parents with normal height [12]. Short parents because of genes in chromosomes that carry short traits are more likely to inherit that short trait to their children. But if the short nature of parents is caused by nutritional or pathological problems, then the short trait will not be inherit to their child [13]. There are individual differences in terms of growth and development, even though the growth pattern is the same for all children. One of the causes of this incident is the difference in the biological and genetic conditions of each individual. For example, in identical twins, even though the 
environment is the same, the response to the environment can be different, depending on the biological condition and genetic potential of the child [14].

\section{Conclusions}

Factors associated with height human is affected by complex interactions among various factor, for example nutrition, parental height, hormonal, environmental and birth weight. There is no significant relationship between the age of menarche and the height of female students in Faculty of Medicine of Warmadewa University. There is a weak relationship in the positive direction between parental height and birth weight with the height of female students in Faculty of Medicine of Warmadewa University.

\section{References}

[1] Batubara, J.R.L. Adolescent Development (Perkembangan Remaja). Sari Pediatri. 2010: 12(1): p. 21-29.

[2] Depkes, R.I. Riset Kesehatan Dasar. 2013. Badan Penelitian dan Pengembangan Kesehatan Departemen Kesehatan RI. Jakarta: 2013.

[3] Gigante, D.P., Horta, B.L., Lima, R.C., Barros, F.C.,Victoria, C.G. Early Life Factors Are Determinants of Female Height at Age 19 Years in a Population-Based Birth Cohort (Pelotas, Brazil). American Society for Nutrition. 2005: 473-478.

[4] Onland-Moret, N.C., Peeters, P.H.M., Gils, V.C.H., Chapelon, C., Key, T., Tjonneland, A., Trichopaulou, A., et al. Age at Menarche in Relation to Adult Height. American Journal of Epidemiology. 2005: 162(7): p. 623-632.

[5] Prasetyarini KA. Hubungan Usia Menarche, Berat Lahir dan Faktor Lainnya Terhadap Tinggi Badan Menurut Umur pada Siswi SMP Negeri 7 Depok Tahun 2012 [skripsi]. Depok: Universitas Indonesia: 2012.

[6] Handayani, R., Irwanto, Purwanti, D., Fatmaningrum, W. Usia Pubertas dan Menarche Terhadap TInggi Badan Mahasiswi Kebidanan. Jurnal MKMI. 2017: 13(1): p. 21-24.

[7] Prendergast, A.J., Humphrey, J.H. The Stunting Syndrome in Developing Countries. Pediatrics and International Child Health. 2014: 34(4): p. 250-265.

[8] Chang, S.H., Tzeng, S.J., Cheng, J.Y., Chie, W.C. Height and Weight Change Across Menarche of Scoolgirl With Early Menarche. Arch Pediatr Aldolesc Med. 2000: 154: p. 880884.

[9] Handayani, S. Hubungan antara Usia Menarche dengan Tinggi Badan pada Mahasiswi Fakultas Kedokteran UNS. PIN PAAI. 2016: p. 83-88.

[10] Candra, A., Puruhita, N., Susanto, J.C. Risk Factors of Stanting among 1-2 Years Old Children in Semarang City. Media Medika Indonesia. 2011: 45: p. 206-211.

[11] Amin, N.A., Julia, M. Infant Stunting is Associated with Short Maternal Stature. J Pediatr Gastroenterol Nutr. 2012: 54(1): p. 117-119.

[12] Supariasa, I., et al. Penilaian Status Gizi. Jakarta: EGC: 2002. Amigo H, Buston P, Radrigan ME. Is There A Relationship Between Parent's Short Height and Their Children's. Social interclass epidemiologic study. Rev Med Chil. 1997: 8: p.125.

[13] Soetjoningsih, Ranuh, I.N.G. Tumbuh Kembang Anak. Jakarta: EGC 